\title{
結晶化ガラス $\left(\mathrm{CaO}-\mathrm{P}_{2} \mathrm{O}_{5}-\mathrm{MgO}-\mathrm{SiO}_{2}-\mathrm{CaF}\right.$ 系) に 関する基礎研究
}

3. in vitro における骨系細胞の初期石灰化に与える影響

吉本 由紀子原興宜* 安部達也宮武祥子 赤峰昭文前田勝正青野正男

九州大学歯学部歯科保存学第一教室

（主任 : 青野正男教授）

*長崎大学歯学部歯科保存学第二講座

(主任 : 加藤伊八教授)

(平成元年 11 月 22 日受付)

\section{Basic Studies on Glass Ceramics}

3. Influence on Calcification of Osteogenic Cells in vitro

\author{
Yukiko YOSHIMOTO, Yoshitaka HARA*, Tatsuya ABE, Sachiko MIYATAKE, \\ Akifumi AKAMINE, Katsumasa MAEDA and Masao AONO \\ Department of Periodontics and Endodontics, Faculty of Dentistry, Kyushu University \\ Maidashi 3-1-1, Higashi-ku, Fukuoka, Japan \\ (Chief : Prof. Masao AONO) \\ *Department of Periodontology, School of Dentistry, Nagasaki University \\ Sakamotocho 7-1, Nagasaki, Japan \\ (Chief : Prof. Ihachi KATOH)
}

Two established osteogenic cell lines (NY, MC $3 \mathrm{~T} 3-\mathrm{E} 1$ ) were used in vitro to determine the biocompatibility of glass ceramics and their effect on initial calcification of osteogenic cells. Morphological study of the cell under the phase-contrast microscopy and histochemical staining were applied as follows. First, glass ceramic granules were placed in $60 \mathrm{~mm}$ dishes, and cells were suspended in the dishes in $\alpha$ MEM supplemented with 10\% FBS (basic medium) or medium with $50 \mu \mathrm{g} / \mathrm{ml}$ of L-ascorbic acid added. After 8 or 14 day of culturing, calcium formation was tested by von-Kossa's staining. Also, alkaline phosphatase staining was performed by the azo-dye method. As controls, cultures in dishes without glass ceramic granules were stained at the same time.
The results obtained in the experimental culture were as follows.

1. Phase contrast microscopy showed that contacts with glass ceramics did not cause cellular death or degeneration.

2. In both cell cultures with the glass ceramics the von-Kossa reaction was positive as early as the 8 th day.

3. The alkaline phosphatase reaction on the 8 th day occurred only in MC $3 \mathrm{~T} 3-\mathrm{E} 1$. The reaction was localized on fibroblastic cells which proliferated three-dimentionally around glass ceramics, and on small polyhedral cells situated relatively for apart from the ceramics.

4. On the 14th day, the MC 3 T 3-E 1 formed large

本論文の要旨は, 第 86 回日本歯科保存学会秋季学会（1988 年 11 月 12 日）において発表した。 
nodules around the glass ceramics, and they were stained uniformly positive by von-Kossa's method. The alkaline phosphatase-positive cells extended spoke-like forms.

5. In medium with L-ascorbic acid, growth of NY was inhibited, After being cultured for 14 days, abundunt von-Kossa positive reaction was found around glass ceramics in both cells. In MC 3 T 3-E 1 on the 8 th days, the alkaline phosphatase reaction was stronger with glass ceramics than with basic medium only.

On the contrary, in the control cultures of both cells there was negative von-Kossa reaction during the culture period. The above results showed that glass ceramic granules have the biocompatibility needed for bone grafts, and they facillitated calcification of MC $3 \mathrm{~T} 3-\mathrm{E} 1$ in culture.

Key words : Glass Ceramics, Osteogenic Cells, Calcification, Alkaline Phosphatase

要旨 : 結晶化ガラスが初期石灰化に与える影響を, in vitro で検討した。まず結晶化ガラス顆粒を静置し, $\alpha-\mathrm{MEM}$ の基礎培地とアスコルビン酸添加培地中で, 骨系細胞 (NY, MC 3T 3-E 1) を 8 日または 14 日間培養した。その後, フォン・コッサ染色とアルカリフォスファターゼ (ALP) 染色を行った。その結果, 基礎培地 8 日目実験群の NY の ALP は陰性で,一部にフォン・コッサ反応が認められた。MC 3T3-E 1 では, ALP の局在とフォン・コッサ反応が一 部に見られ，14 日目には放射状の ALP 反応とフォン・コッサ反応が観察された。なお, 両細胞とも対照群のフォ ン・コッサ反応は認められなかった。次にアスコルビン酸添加培地では, NY の培養期間が 14 日に延長され，実験群 のみフォン・コッサ反応を認めた。MC 3T3-E 1 では対照群より強いフォン・コッサ及び ALP 反応が観察された。 以上より，両培地中とも結晶化ガラスが MC 3T3-E 1 の石灰化を亢進させる可能性があると考えられた。

索引用語 : 結晶化ガラス, 骨系細胞, 石灰化, アルカリフォスファターゼ

\section{緒言}

近年, 歯周疾患に罹患した歯の 2 壁性， 3 壁性の垂直 性骨欠損に対し，骨整形や骨切除に代わる骨修復方法と して，人工骨移植材の使用が盛んに行われるようになっ てきた。なかでも，ハイドロキシアパタイトや $\beta-\mathrm{TCP}$ を代表とするリン酸カルシウム系セラミック材料が注目 を集めている。しかし，これらの材料も骨再生を促進さ せる理想的な骨移植材とは言えず，生体新素材の開発は 今なおさかんである1)。

今回実験に使用した結晶化ガラスは，ハイドロキシア パタイト結晶のガラス相にアパタイトとウォラストナイ トおよびディオプサイドを含有しており，生体内で線維 性被膜を形成せず直接化学的に骨と結合するという能力 を持ち, しかもガラスの物理学的特質として 融点が低 く, 熱処理して結晶化させることにより, 機械的強度の 向上をはかることができる2)。

我々は，この結晶化ガラスをインプラント材や骨移植 材として臨床応用するに先だち, 結晶化ガラスプレート を用いた in vitro における基礎研究を行ってきた ${ }^{3,4)}$ 。そ の結果, 位相差顕微鏡的にも超微形態的にも, 結晶化ガ ラスに細胞障害性がないことが示された。今回は，骨移
植材としての有用性を検定する目的で, 前回 同様の in vitro 実験系において, 結晶化ガラス顆粒の細胞親和性を 位相差顕微鏡下で観察し, さらにアルカリフォスファタ 一ゼ活性を指標として，骨系細胞の初期石灰化に及ぼす 影響を組織細胞化学的に検索した。

\section{実験材料および方法}

\section{1. 実験材料}

実験材料は, 日本電気硝子社製の結晶化ガ ラ ス 顆 粒

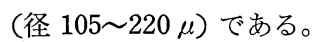

実験に使用した培養細胞は, JCRB 細胞バンクより供 与を受けたヒト骨肉腫由来の $\mathrm{NY}^{5)}$, および明海大学久米 川正好教授より供与されたマウス頭蓋骨由来の骨原性細 胞株 MC 3T3-E 16) である。

\section{2. 培養方法}

培地には，基礎培地として Eagle の $\alpha$-MEM (Gibco Laboratories, Grand Island, NY) に FBS 10\% (M.A. Bioproducts, Walkerswille, MD) を用いた。今回は, これにさらに $50 \mu \mathrm{g} / \mathrm{m} l$ の L-アスコルビン酸 (半井化学 薬品, 東京) を加えた培地中での培養を行った。培養条 件は前回の報告 ${ }^{3)}$ に準じて行った。 


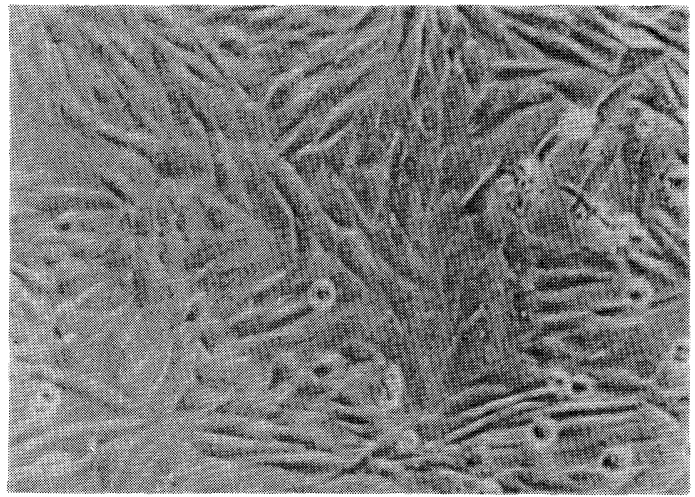

Fig. 1-A Phase-contrast microscopic appearance of NY after 8 days in a control culture. This reached subconfluence at this time. $(\times 200)$

\section{3. 実験方法}

1）位相差顕微鏡による観察

まず径 60 mm ディッシュ (Falcon 3002, Becton Dickinson, Cockeysville, MD) に結晶化ガラス顆粒を静置 しておき，NYを $9.0 \times 10^{4} \mathrm{cells} / \mathrm{m} l, \mathrm{MC} 3 \mathrm{~T} 3-\mathrm{E} 1$ を $6.0 \times 10^{4} \mathrm{cells} / \mathrm{m} l$ の密度で上記の各培地に懸濁して播種 した。そして, 適宜位相差顕微鏡下で細胞の形態や増殖 状態について観察を行いながら，8 日または 14 日間培 養を行った。培地は 1 週間に 2 回交換した。 8 日目以降 は 1 日拉きに培地交換を行った。なお, 対照として結晶 化ガラスを入れない細胞だけの培養を同様の条件にて行 った。

\section{2) 石灰化染色}

各ディッシュ上の細胞を PBS (一) (日水製薬，東京） で洗浄し, $100 \%$ エタノールで固定した後, フォン・コ ッサ染色7) を行った。なお，フォン・コッサ染色は組織 または細胞中の不溶性リン酸カルシウムを証明する方法 であるが, 結晶化ガラス自体がリン酸カルシウムの結晶 で覆われており, 培地中へ溶出して false positive の反 応を呈する可能性がある。そこで, 石灰化しない細胞で あるヒ卜歯肉癌由来の Ca 9-22, ヒ卜線維肉腫由来の HT-10803,4) についても同様の実験を行った。

\section{3）酵素染色}

まず各細胞を PBS (一) で洗浄し, $100 \%$ メタノール または $10 \%$ 中性ホルマリンで固定した ${ }^{8,9)}$ 。次に, 蒸留 水で洗浄後, Burnstone ${ }^{10)}$ のアゾ色素法に従ってアルカ リフォスファターゼ染色を行った。基質には, naphtol AS BI phosphate (Sigma, St. Louis, MO), ジアゾニウ ム塩として fast red violet LB salt (Sigma, St. Louis,

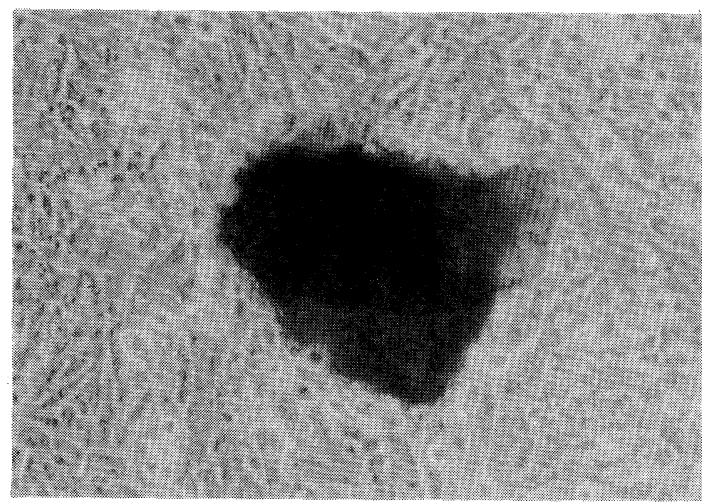

Fig. 1-B Phase-contrast microscopic appearance of NY after 8 days in an experimental culture. Locally proliferated areas around glass ceramics were many seen. Attached cells to glass ceramics did not die or degenerate. $(\times 200)$

$\mathrm{MO}$ ）を使用し， $37^{\circ} \mathrm{C}$ で 30 分反応を行った。なお基質を 除いた反応液中での浸漬, および阻害剂として $5 \mathrm{mM} の$ levamizole (Sigma, St. Louis, MO) を用いたところ, 両者とも陽性反応は見られなかった。

\section{結 果}

\section{1. 基礎培地における培養}

1）位相差顕微鏡による観察

(1) NY

培養開始 24 時間で, 一部の細胞が対照群, 実験 群 と もディッシュに接着した。実験群において結晶化ガラス 顆粒に付着する細胞が一部の結晶化ガラスに見られた が, 多くは 3 日後の対数増殖期にはいってから付着し, その後経時的に結晶化ガラス周囲の細胞数は増加した。

8 日間培養後対照群, 実験群ともに subconfluent に 達した (Fig. 1-A，B)。結晶化ガラスに付着した細胞は, 紡錘形の形態をしたものが多かった。その後も引き続き 培養し観察を続けたが, 死滅する細胞が多くなり, 両群 とも 14 日間培養することはできなかった。なお， 8 日間 の培養期間中に結晶化ガラス顆粒に付着した細胞の死滅 像や核濃縮, 核融解などの変性像を示す所見は見られな かった。

\section{(2) MC 3T3-E 1}

培養開始 24 時間以内に対照群, 実験群ともディッシ ュに接着した。結晶化ガラス顆粒に, 細胞質突起の先端 や細胞質の広い面積で付着する細胞が培養開始 6 時間後 


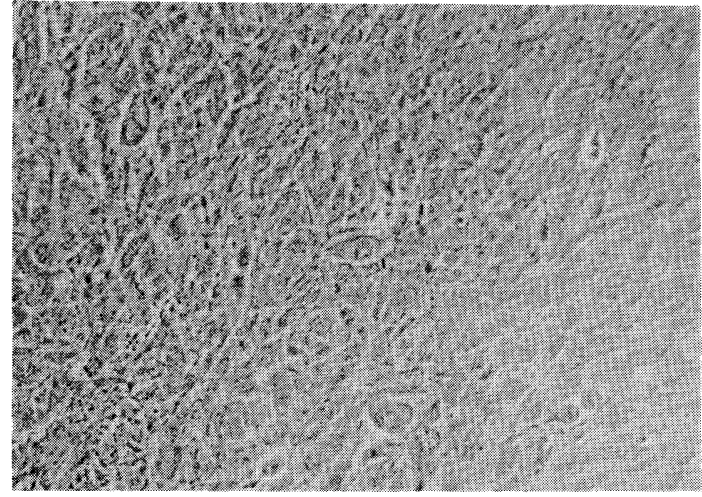

Fig. 2-A Phase-contrast microscopic appearance of MC3T3-E1 after 8 days in a control culture. This had already reached confluence. Fibroblastic cells proliferated overlapping each other. $(\times 200)$

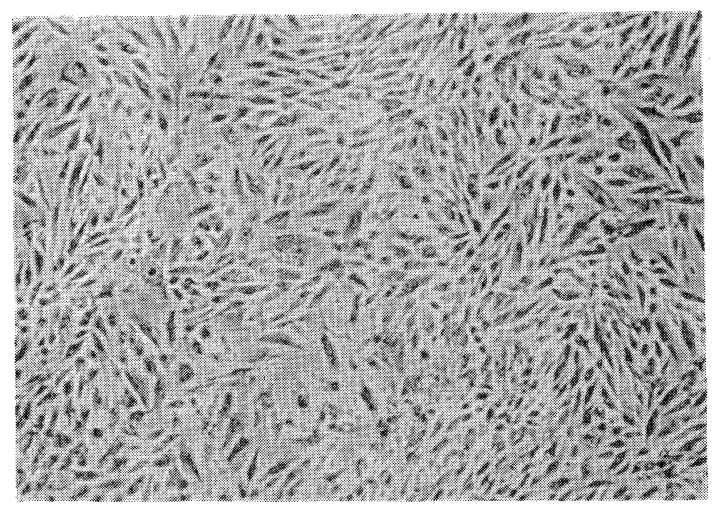

Fig. 3-A A photomicrograph of NY at 8th day stained with von-Kossa's method. No positive reaction was found in a control culture. $(\times 100)$

ですでに見られ, 24 時間後では多くの細胞が付着してい た。その後, 経時的に結晶化ガラスに付着する細胞は増 加した。対照群, 実験群とも 3 日閒培養後 subconfluent に達し, 多角形の細胞がディッシュ全体を被っていた。

4 日目では, 対照群に polygonal な形態をとる細胞が 一部に認められた。一方実験群では，4 日目以降の confluent 形成後では, 一部の結晶化ガラス顆粒に接し た細胞が伸展され, その周囲では核や細胞質の存在が不 明瞭である扁平な細胞が結晶化ガラスを平行に取り囲む ようにして三次元的に増殖していた。

8 日目の対照群は, 球状や紡錘形の細胞が多層化して いた (Fig. 2-A)。実験群では, 結晶化ガラスを中心とし て, 光屈折性の結節 ${ }^{18)}$ が形成されていた (Fig. 2-B)。

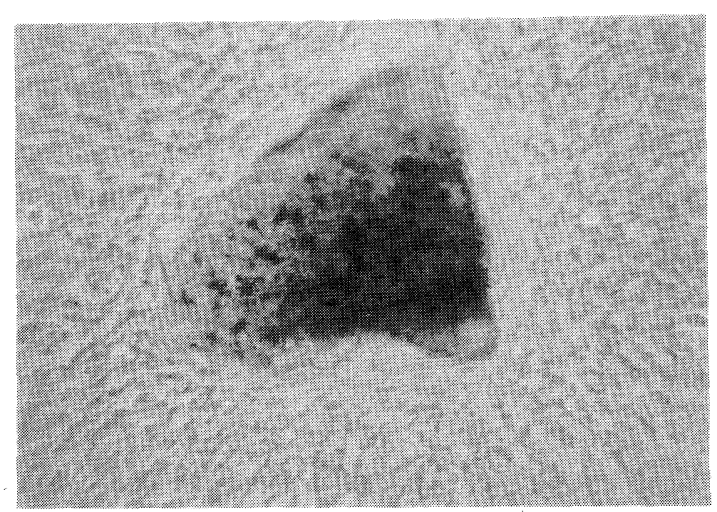

Fig. 2-B Phase-contrast microscopic appearance of MC3T3-E1 after 8 days in an experimental culture. Note growth pattern with regular a way of morphometric spindle cells of which the nucleus was not clear piled up three dimentionally around glass ceramics. $(\times 200)$

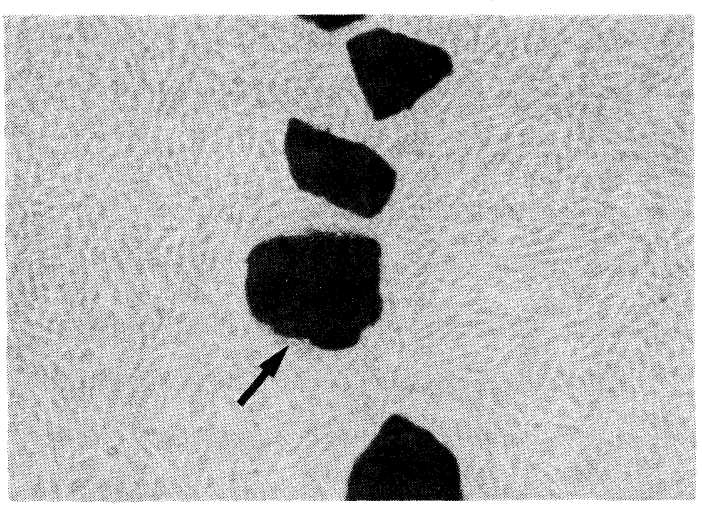

Fig. 3-B A photpmicrograph of NY, cultured with glass ceramics at 8 th day, stained with von-Kossa's method. Only small number of positive reactions were found (arrow), but the majority of contact cells to glass ceramics were negative. $(\times 100)$

その後も引き続き培養を続け, 14 日間培養を行ったと ころ, 対照群は細胞質内に大小さまざまな空胞状構造物 を持つ紡錘形細胞や，よく伸展した多角形の細胞が相互 に重積しあって増殖を続けていたが，局所的に結節が形 成される所見はなかった。実験群では，扁平な細胞が取 り囲む光屈折性の結節の範囲が次第に増大した。結晶化 ガラスから離れた部位においては, 対照群同様の紡鍾形 やよく伸展した多角形の細胞が相互に重積していた。な 


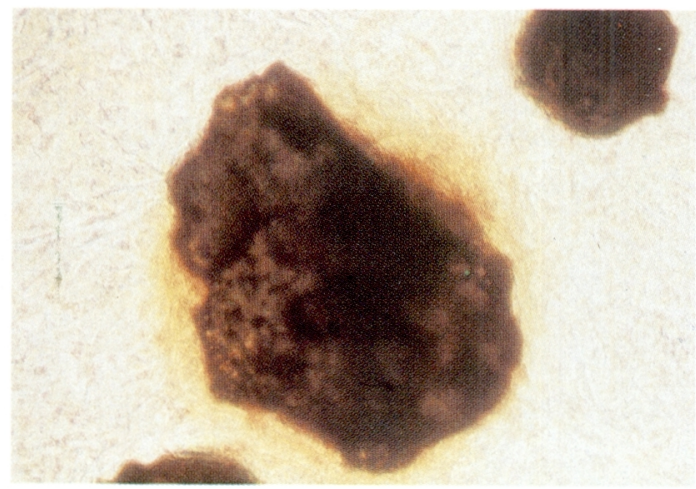

Fig. 4-A A photpmicrograph of MC3T3-E1, cultured with glass ceramics at 8 th day, stained with von-Kossa's method. Positive reactions by silver-nitrate were partly found around glass ceramics. $(\times 200)$

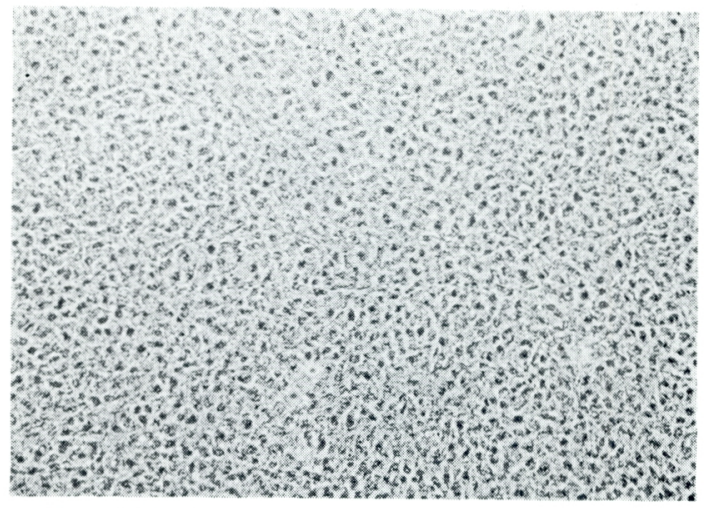

Fig. 5-A A photomicrograph af MC3T3-E1 at 14 th day, stained with von-Kossa's method. No mineral deposits were found in a control culture as yet. $(\times 100)$

お, MC 3T3-E 1 の実験群において, 細胞死滅像などの 細胞障害性を示寸所見は見られなかった。

2) 石灰化染色

(1) NY

8 日閒培養後フォン・コッサ染色を施すと, 対照群は 陰性であった（Fig. 3-A)。実験群では結晶化ガラスと 接した部位に，茶褐色に染色される細胞がごく少数見ら れるディッシュもあった（Fig. 3-B)。その陽性反応は， 複数の結晶化ガラスが接触し, かつ細胞増殖の密な部分 で連続的に見られる場合が多かった。

(2) MC 3T3-E 1

8 日目のフォン・コッサ染色では, 対照群の陰性に対

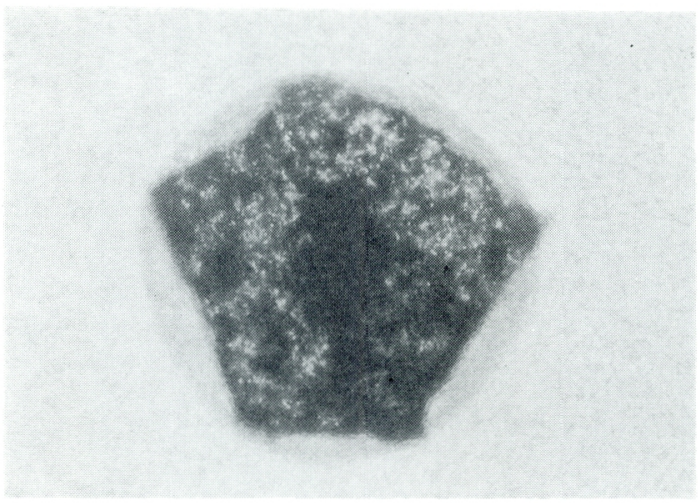

Fig. 4-B A photpmicrograph of MC3T3-E1, cultured with glass ceramics at 8 th day, stained with von-Kossa's method. Different type of positive reaction by silver-nitrate. $(\times 200)$

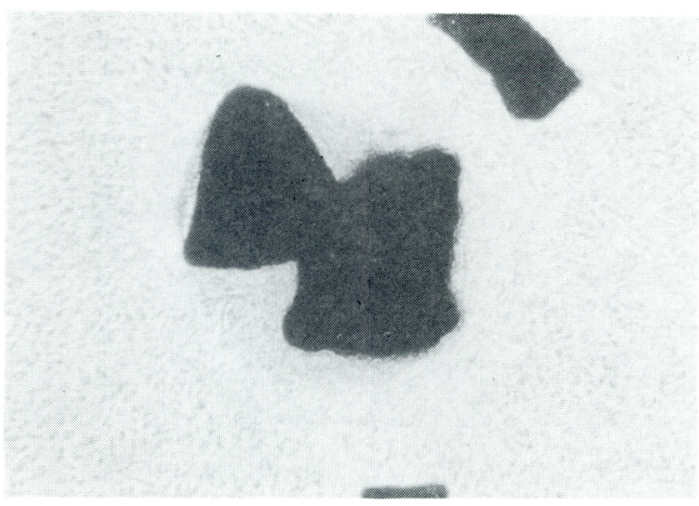

Fig. 5-B A photomicrograph of MC3T3-E1, cultured with glass ceramics at 14 th day, stained with von-Kossa's method. Positive reaction was found more than that of 8 th day. $(\times 100)$

して，実験群では結晶化ガラスと接した部位に，数層陽 性に染色される細胞が見られた（Fig．4-A)。その陽性 反応は, 結晶化ガラスが集積している部分では強い傾向 にあった。陽性反応の範囲は, 結晶化ガラス顆粒の大き さや形状に関係なく，顆粒間でかなり異なっていた。ま た，中には 1 つの顆粒を取り囲んで明瞭な境界線を持 ち, 円形に染色される反応が見られた細胞群もあった (Fig. 4-B)。

14 日間培養後対照群は陰性であったが, 実験群はほぼ 一定の範囲で陽性であった（Fig. 5-A，B）。また，一部 のディッシュにおいて, 結晶化ガラスから離れた部位に 陽性反応を示す細胞小塊が認められた (Fig. 5-C)。 


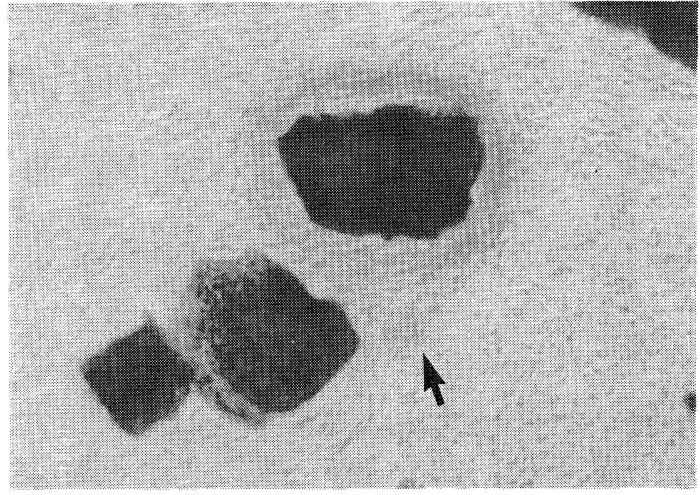

Fig. 5-C A photpmicrograph of MC3T3-E1, cultured with glass ceramics at 14 th day, stained with von-Kossa's method. Different type of positive reaction by silver-nitrate. Note the reaction apart from the glass ceramics (arrow). ( $X$ 100)

(3) Ca 9-22, HT-1080

Ca 9-22, HT-1080 の 8 日間培養後のフォン・コッサ 染色では，対照群・実験群ともに陰性であった。

3）アルカリフォスファターゼ染色

(1) NY

対照群，実験群とも培養期間中，明瞭な陽性所見は認 められなかった。

(2) MC 3T3-E 1

8 日目の染色で, 対照群はディッシュ全体に散在する 陽性反応が見られた (Fig. 6-A)。また陽性反応は，多角 形の細胞と紡錘形細胞が交錯している部位で多く認めら れた。実験群でも同様に陽性反応が観察された。陽性細 胞の形態は, 結晶化ガラス周囲で三次元的に増殖した扁 平な細胞の一部, および小型多角形の細胞群であった (Fig. 6-B)。また, 結晶化ガラスから離れた部位では, 細長い突起を有した細胞に陽性反応が見られた。

14 日目になると, 対照群は 8 日目よりも多くの陽性反 応が認められたが，依然陽性細胞は散在していた（Fig. 7-A)。一方実験群では, 結晶化ガラスを中心として放射 状に陽性反応が認められた。ディッシュ全体の陽性細胞 数は, 対照群よりやや多い程度になっていた（Fig. 7B)。また, 陽性細胞の形態としては長い突起を有するも のが 8 日目よりも多かった。そして, 結晶化ガラスに対 して鋭角に付着する陽性細胞が多く観察された。
2. L-アスコルビン酸添加培地における培養

(1) NY

L-アスコルビン酸添加により, 対照群, 実験群とも増 殖は抑えられ，14 日に培養期閒が延長された。14 日目の フォン・コッサ染色での対照群は, 局所的に過密状態と なった部分で, 変性した細胞の小塊が茶褐色に染色され た場合以外は陰性であった（Fig. 8-A)。実験群の結晶 化ガラス周囲では，基礎培地で培養した場合よりも多く の陽性反応が認められた（Fig. 8-B)。

なお, アルカリフォスファターゼ染色での陽性反応 は, 培養期間を通じて対照群, 実験群ともに認められな かった。

(2) MC 3T3-E 1

対照群 8 日目のフォン・コッサ染色では, 基礎培地と 同様に陰性であった。実験群では基礎培地との染色範囲 の差はほとんど認められなかったが, 結晶化ガラス周囲 の陽性反応数が基礎培地よりも多かった。また, 基礎培 地同様に，結晶化ガラスが集積している部位では陽性反 応が多く認められた。

14 日目のフォン・コッサ染色では, 対照群のわずか一 部に細胞小塊を示す陽性反応が認められた (Fig. 9-A)。 実験群では，基礎培地同様の範囲で陽性反応が認められ た (Fig. 9-B)。

次に 8 日目対照群のアルカリフォスファターゼ染色に おいて, 基礎培地との染色性の変化は明瞭ではなかった (Fig. 10-A)。実験群では, 結晶化ガラスに接した扁平 な細胞に陽性反応が多く見られた (Fig. 10-B)。

14 日目になると, 対照群は扁平な細胞や長い突起を有 する細胞が局所的に集合し，その部位に一致して陽性反 応が見られた。しかし，ディッシュ全体の陽性細胞数は 基礎培地よりも少なかった。実験群では, 結晶化ガラス から離れた部位の陽性細胞数は基礎培地よりも少なかっ たが，結晶化ガラスに近接した部位では，放射状に観察 された。

\section{考察}

\section{1. 結晶化ガラス顆粒と骨系細胞との親和性}

一般に位相差顕微鏡下で細胞障害性を表す所見として は, 細胞死滅像, 核の腫大, 多核化, 細胞質の空胞形 成, 細胞質の融解像などがある。また, 生体活性材料の 細胞親和性の評価は特に cell granurality, 細胞の rounding up, monolayer formation などを考慮して, 総 合的になされるべきであると言われている11)。 


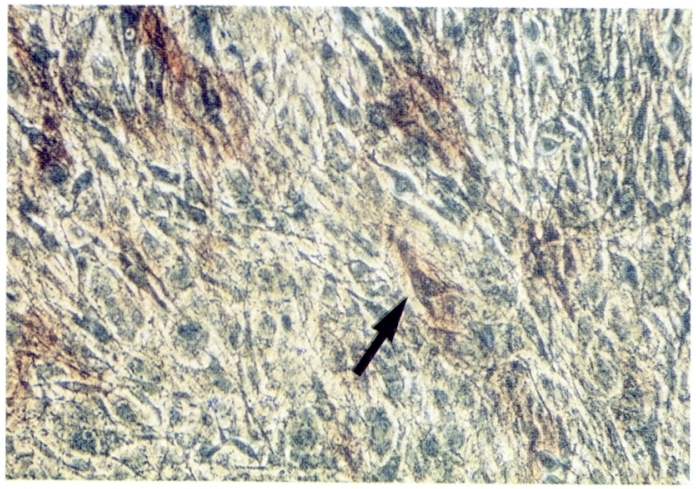

Fig. 6-A Alkaline phosphatase staining of MC3T3-E1 at 8th day. Alkaline phosphatase positive cells (arrow) were distributed on the dish. $(\times 200)$

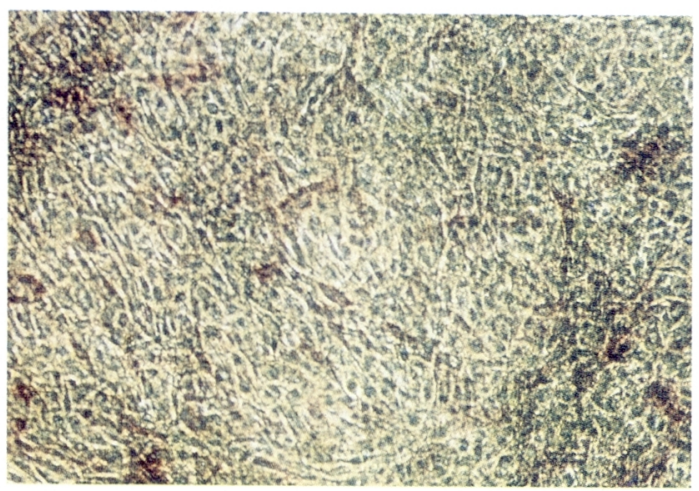

Fig. 7-A Alkaline phosphatase staining of MC3T3-E1 at 14th day. Alkaline phosphatase positive cells were distributed in the dish. $(\times 100)$

今回の実験結果から，まず，NY では結晶化ガラスの 一般的な細胞障害性を示寸所見は見られなかったが， monolayer formation に関しては, 局所的に細胞が増殖 する傾向があるために不良である場合もあった。しか し, 対照群でも同様の傾向が見られたため, 細胞障害性 はないと判断した。

次に, MC 3T3-E 1 では初期付着後の細胞の核は対照 群同様に明瞭であった。この所見は, cell granurality が良好であることを意味するものと思われた。6日目以 降の培養では，結晶化ガラスから離れた部位の細胞質内 に, 空胞様構造物を有する細胞が観察された。この細胞 は対照群でも同様に見られたため, MC 3T3-E 1 の分化 過程の一段階で出現するもの 12 ) と考えた。

以上の位相差顕微鏡所見から，結晶化ガラスプレー ト ${ }^{3,4)}$ と同様に顆粒状であっても良好な生体適合性が期

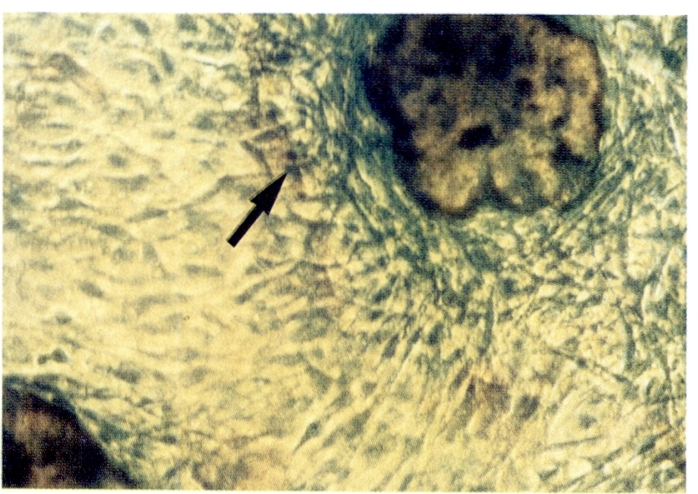

Fig. 6-B Alkaline phosphatase staining of MC3T3-E1, cultured with glass ceramics at 8 th day. Partly positive reactions were found around glass ceramics, from which they situated relatively apart (arrow). $(\times 200)$

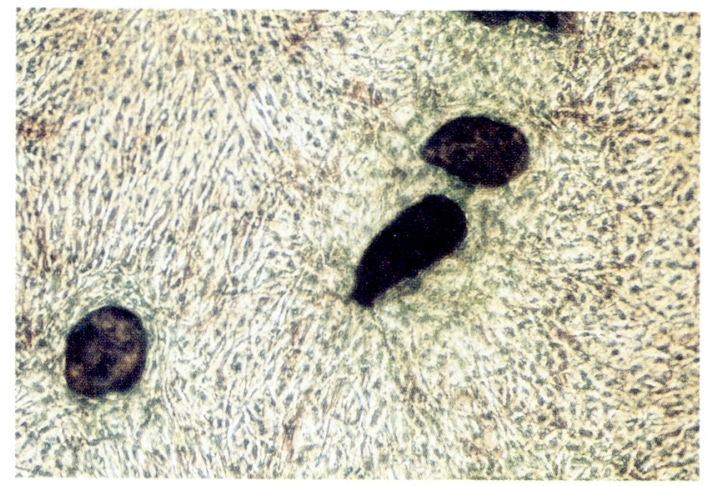

Fig. 7-B Alkaline phosphatase staining of MC3T3-E1, cultured with glass ceramics at 14 th day. Alkaline phosphatase positive cells were extended spoke-like form. $(\times 100)$

待できるものと判断した。

2. 結晶化ガラスが骨系細胞の初期石灰化に与える影 響

一般に骨形成細胞の初期石灰化過程とは，骨の無機成 分を構成しているリン酸カルシウム（ハイドロキシアパ タイト結晶）が析出するための核形成の過程と定義され る ${ }^{13)}$ ここのリン酸カルシウムを光䫓レベルで組織細胞化 学的に検出する方法としては, アリザリン・レッド-S染 色とフォン・コッサ染色がある8,14)。

しかし, 結晶化ガラスは材料自体がリン酸カルシウム の結晶で覆われており, 再結晶したアパタイト相や培地 中に溶出した成分が擬陽性反応をおこす可能性がある。 


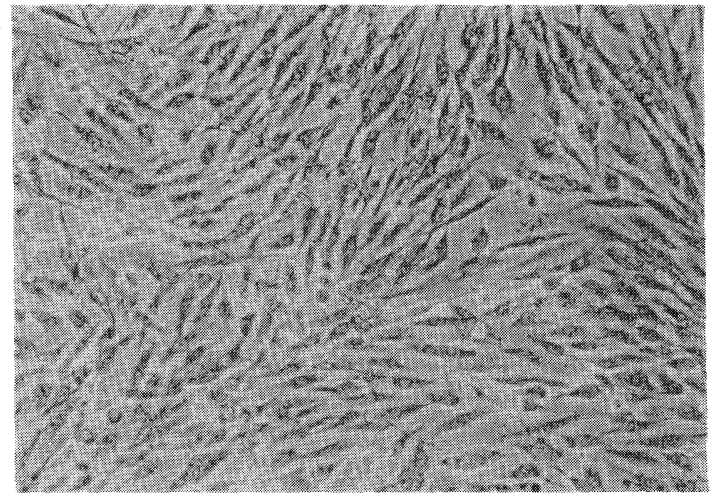

Fig. 8-A A photpmicrograph of NY cultured in the medium supplemented with L-ascorbic acid at 14 th day, stained with von-Kossa's method. No positive reaction was present. $(\times 200)$

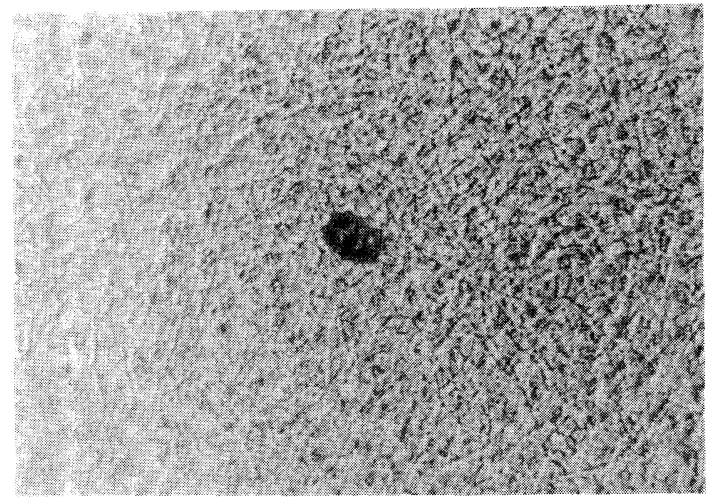

Fig. 9-A A photomicrograph of MC3T3-E1 cultured in the medium supplemented with L-ascorbic acid at 14th day, stained with von-Kossa's method. Small number of positive cells in some cultures were present, but majority of cells were negative. $(\times 100)$

そのため，本来石灰化しないはずの骨系細胞以外の細胞 に反応が生じることも充分考えられる。

そこで, 実験前に 2 種類の対照実験を行った。まず最 初に, 軟寒天培地中に結晶化ガラスのみを置き, 24 時間 以上 $37^{\circ} \mathrm{C}$ に保った後, 石灰化染色としてアリザリン・ レッド-S 染色およびフォン・コッサ染色を施した。そ の結果, アリザリン・レッド-S においてのみ, 結晶化ガ ラス周囲にリング状の陽性反応が観察された。次に，非 石灰化細胞系統と考えられる上皮系腫漡細胞 $\mathrm{Ca} 9-22$, および結合織系腫瘍細胞 HT-1080 の培養系では, Ca 9-

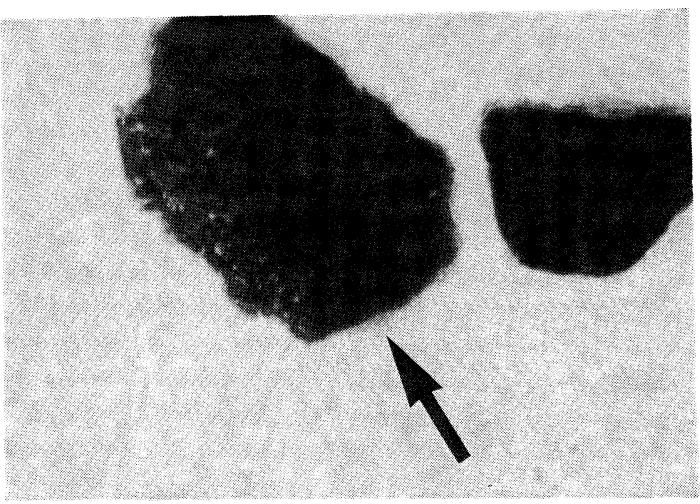

Fig. 8-B A photomicrograph of NY cultured with glass ceramics in the medium supplemented with L-ascorbic acid at 14th day, stained with von-Kossa's method. Positive reactions were occasionally present (arrow). $(\times 200)$

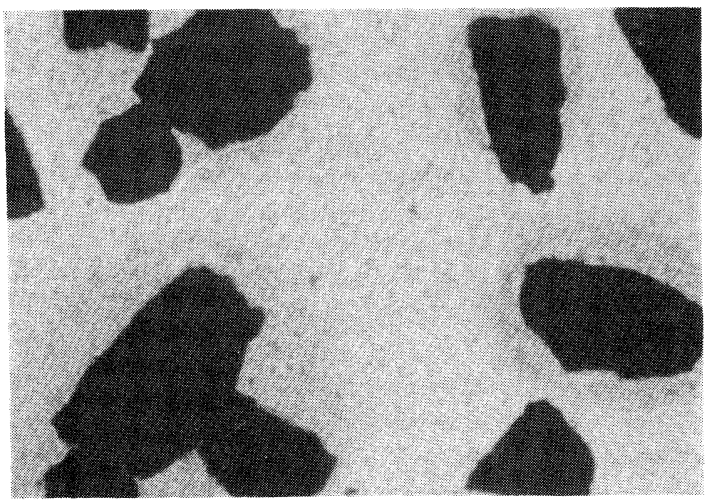

Fig. 9-B A photpmicrograph of MC3T3-E1, cultured with glass ceramics in the medium supplemented with L-ascorbic acid at 14 th day, stained with vonKossa's method. An extent of positive reaction was almost the same as the reaction of the control medium. $(X$ 100)

22 の実験群において, アリザリン・レッド-S 染色で, リ ング状の陽性反応が一部の結晶化ガラスに接して見られ た。従ってアリザリン・レッド-S 染色は, 少なくとも今 回の実験において，石灰化の状態を検出する方法として は不適当であると思われた。

個々の細胞の反応について，まず NY 8 日目実験群の フォン・コッサ陽性所見は，一般に石灰化の指標とされ ているアルカリフォスファターゼ活性が観察されなかっ たことや，陽性反応が細胞形態とは関係なく細胞基質と 


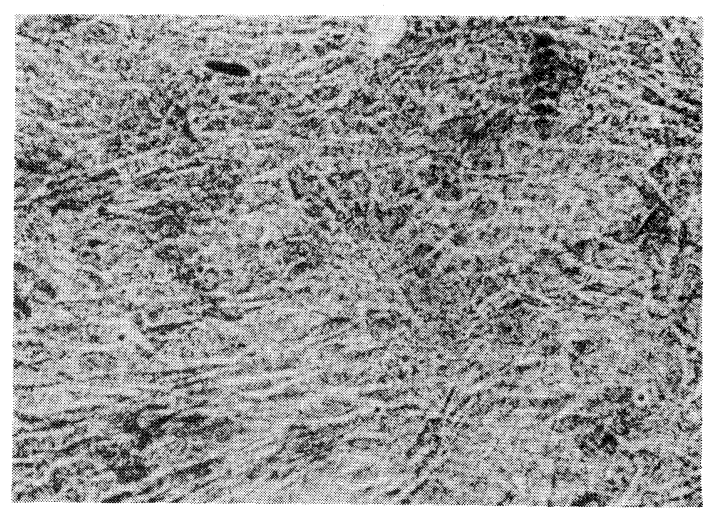

Fig. 10-A Alkaline phosphatase staining of MC3T3-E1 cultured in the medium supplemented with L-ascorbic acid at 8 th day. $(\times 200)$

思われる部分でも見られたことから，石灰化現象とは考 え難かった。これは，先の報告4) で見られた連続する基 底板様構造物などの細胞外基質に, 結晶化ガラスから溶 出したリン酸カルシウムが吸着していたためかもしれな い。

一方，MC 3T3-E 1 の陽性反応は石灰化であると，二 つの理由から判断した。まず第一の理由は, 対照群石灰 化時の結節周囲に形成される扁平な細胞と同様の細胞 が, 結晶化ガラス周囲で多層化した細胞群中に見出され る点である。第二には, 結節周囲にアルカリフォスファ ターゼ陽性細胞が局在して見られることが挙げられる。 なお, MC 3T3-E 1 の通常の石灰化は 18 日目に起こりは じめるとされている(2)ので, 結晶化ガラス周囲にアルカ リフォスファターゼ陽性細胞の局在が認められる部位で は, 石灰化開始時期が幾分早くなっている可能性があ る。

\section{3. アルカリフォスファターゼ活性に及ぼす影響}

アルカリフォスファターゼは骨誘導性細胞（未分化間 葉系細胞, 骨芽細胞, 軟骨芽細胞) の分化マーカーの一 つとして認められている15,16)。NY については, 骨系細 胞由来ではあるが, 対照群・実験群ともにアルカリフォ スファターゼ活性は認められず, 骨芽細胞の性質とは異 なっていた。

MC 3T3-E 1 は confluent 形成後からアルカリフォス ファターゼ活性を上昇させ, 石灰化に向けて準備段階に はいるとされている。MC 3T3-E 1 を結晶化ガラスプレ 一ト上で培養し, 生化学的に検索した安井らの報告 ${ }^{17) て ゙ ~}$ は, 培養 9 日目から急激にアルカリフォスファターゼ活 性の上昇を示し, 15 日目には対照のプラスチックカバー

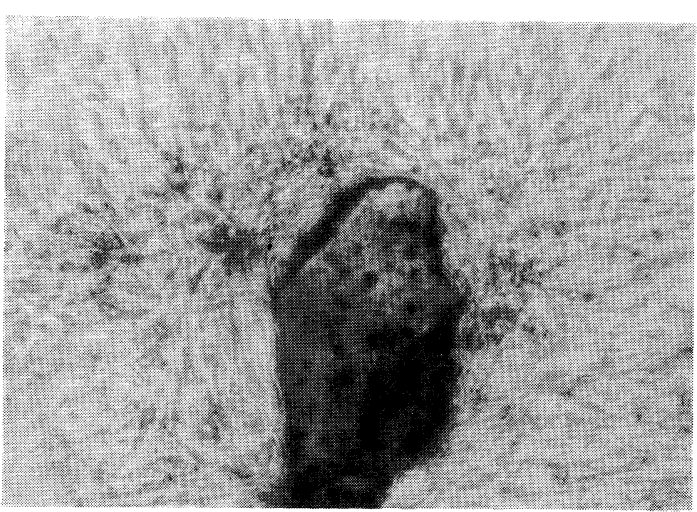

Fig. 10-B Alkaline phoshatase staining of MC3T3-E1, cultured with glass ceramics in the medium supplemented with L-ascorbic acid at 8 th day. Positive reactions were investigated at the morphometric spindle cells attached to glass ceramics. $(\times 200)$

スリップの 2 倍弱の活性が観察されたとしている。

今回の我々の実験では，8 日目の結晶化ガラスに接し た部分ではアルカリフォスファターゼ反応は陰性であっ たが，多層化している扁平な細胞の外周に，また結晶化 ガラスから離れた部位の小型多角形の細胞に陽性反応を 認めた。さらに 14 日目では対照群における散在性の陽 性反応に対して, 実験群では結晶化ガラスから放射状に 伸びる反応が観察された。このようなアルカリフォスフ アターゼ陽性細胞の形態变化や, 結晶化ガラスとの相対 的位置関係が石灰化機構といかなる関連を有するのかに ついては不明であり, 興味がもたれる点であるので, 今 後は超微形態的にアルカリフォスファターゼ陽性細胞と 石灰化との関係を観察していく予定である。

\section{L-アスコルビン酸添加培地における培養結果}

アスコルビン酸がコラーゲン合成に必須の因子である ことは，一般に in vivo でよく知られているが, 近年 in vitro においてコラーゲン合成及び石灰化を促進する目 的で, 培地中に $\beta$-glycerophsphate とともに生理的濃 度で加えられるようになった ${ }^{18 \sim 20)} 。$

今回の実験結果から, NY に対しては L-アスコルビン 酸の付加により増殖が抑制され, 14 日間の培養が可能と なった。実験群での培養期間の継続によって, フォン． コッサ陽性反応数の増加が見られたものの, アルカリフ オスファターゼ活性が認められなかったのは, 基礎培地 における培養時に観察された際と同じ理由と思われる。 次に, MC 3T3-E 1 培養系 8 日目のアルカリフォスフ 
アターゼ染色では，陽性細胞が結晶化ガラスに接した部 位で基礎培地の場合と比較して多く見られた。一般に, 生理的濃度のアスコルビン酸は MC 3T3-E 1 のアルカ リフォスファターゼ活性を増加させ，コラーゲン合成を 活発にすることによって結晶沈着の足場を与えるとされ ている ${ }^{21)}$ 。今回の結果は, 結晶化ガラスが L-アスコル ビン酸付加によって扁平化した細胞のアルカリフォスフ アターゼ活性上昇を引き起こし, その結果コラーゲン産 生を増し, 結晶沈着の足場を与えると考えた。

しかし, 14 日目の染色でアルカリフォスファターゼ陽 性細胞が対照群, 実験群とも基礎培地よりも少なかった のは，すでに石灰化した部位ではアルカリフォスファタ 一ゼ活性が低下していたと判断した。なお, MC 3T3-E 1 が産生したコラーグン性の基質と早期に石灰化した部位 でのアルカリフォスファターゼ活性低下との関係につい て言及した報告はなく，その意義については現在のとこ ろ解明されていない。

\section{5. 結晶化ガラス周囲の石灰化機構について}

骨移植材に必須とされる性質として, 細胞親和性はも ちろんであるが，三木 ${ }^{22)}$ らは移植材と骨系細胞の結合が 最も重要であると述べている。これに関して彼らは， osteoprogenitor cells, osteoblasts, obteocytes 等生き た細胞の移植材への生着や，骨誘導，骨伝導の 3 つの過 程をあげ，このうち 1 つでも起これば結合はされるとし ている。

今回の検索のうち, MC 3T3-E 1 培養系において, 8 日 という早期からアルカリフォスファターゼ陽性細胞の局 在と同時にフォン・コッサ陽性反応が認められ，L-アス コルビン酸添加や培養期間の進展にともなってフォン・ コッサ陽性反応が増強された。このことから, 結晶化ガ ラスは MC 3T3-E 1 の L-アスコルビン酸添加培地にお いても，何らかの機序で石灰化を促進することが考えら れる。

次に MC 3T3-E 114 日目の実験群では, 結晶化ガラ スから離れた部位の細胞小塊にフォン・コッサ陽性反応 が観察された。今回の結果には示していないが, 21 日間 培養後この反応数は増加していた。これは, 14 日目以降 の対照群に観察された石灰化小塊と同様の反応を呈して いるため, 離れた部位に存在する未分化間葉系細胞の分 裂，分化を結晶化ガラスが促進したと考えるよりも，離 れた部位に存在する細胞が若干早く対照群同様の石灰化 を開始した現象であると考える方が妥当であるう。

最後に, 今回 in vitro で得られた結果が正常骨芽細胞 に対しても適応されるかについては, in vivo での動物実
験により検索を続けていく予定である。

\section{結 論}

結晶化ガラスが in vitro におおる骨系細胞の初期石灰 化に与える影響を， 2 種類の骨原性細胞株 (NY, MC 3 T 3-E 1) を用いて検索を行い以下の結果を得た。

1. 位相差曊微鏡による観察からは, 結晶化ガラス顆 粒の良好な細胞親和性が観察された。

2. 8 日間培養後のフォン・コッサ染色では, NY 培 養系では対照群のフォン・コッサ陽性反応は見られなか ったが，実験群では結晶化ガラスに接した部位で一部陽 性反応が見られた。MC 3T3-E 1 対照群ではフォン・コ ッサ陽性反応は見られなかったが，実験群では一部広範 囲で陽性反応が認められた。その傾向は L-アスコルビ ン酸添加により増強されており, 14 日間培養後には, 多 くの結晶化ガラス周囲で陽性所見が観察された。

3. アルカリフォスファターゼ染色では, 陽性反応は MC 3T3-E 1 のみに見られた。8日目では, 実験群の結 晶化ガラスから離れた一部の少数の細胞に陽性であっ た。14 日目では, 対照群の散在性の陽性反応に対して, 実験群では結晶化ガラスを中心に放射状に伸びて観察さ れた。L-アスコルビン酸添加培地の実験群では，8 日目 から多数の結晶化ガラスに接した部位で陽性反応が観察 された。

\section{謝 辞}

稿を終えるにあたり，ご贸篤なご指導とご校閲を賜りました 近畿大学九州短期大学保育科岡野博光教授に感謝の意を表しま す。また, MC3T3-E1 を供与いただきました, 明海大学歯学部 口腔解剖学第一講座久米川正好教授, および貴重なご教示をい ただきました九州大学歯学部口腔解剖学第二教室栗栖浩二郎教 授に御礼を申し上げます。なお, 本研究の一部は昭和 63 年度文 部省重点領域研究 I（課題番号 63604019）及び Bioramics 研 究会研究助成金の援助により行われたことを付記する。

\section{文献}

1）青野正男, 原 宜興: 人工骨骨移植材の進歩. 歯 科ジャーナル, $28: 748-754,1988$.

2）松井 昌, 渋谷武宏 : Bioramics の場における生 体機能ガラスセラミックスの開発研究. IV. 特に 顎骨内応用を目的とした生体活性ガラスセラミッ クス $\left(\mathrm{CaO}-\mathrm{P}_{2} \mathrm{O}_{5}-\mathrm{MgO}-\mathrm{SiO}_{2}-\mathrm{CaF}\right.$ 系結晶化ガラ ス）創成と応用に関する研究. ザ・クインテッセ 
ンス, $7: 1122-1138,1988$.

3）吉本由紀子, 原 宜興, 安部達也, 赤峰昭文, 前 田勝正, 青野正男 : 結晶化ガラスに関する基礎研 究 1. 位相差顕微鏡による形態学的観察および細 胞増殖について. 日歯周誌, $31: 640-650,1989$.

4) 原 宜興, 吉本由紀子, 安部達也, 赤峰昭文, 前 田勝正, 青野正男 : 結晶化ガラスに関する基礎研 究 2. 培養細胞と結晶化ガラス界面の透過型電子 顕微鏡的観察. 日歯周誌, $31: 651-657,1989$.

5) Sekiguchi, M., Asanuma, K., Satomura, T., Fukushima, H., Fuzi, G., Shimoda, T., Fukunaga, M. and Ishikawa, E. : A cultured cell line established in vitro from human osteosarcoma. Jpn. J. Exp. Med., 53 : 289-292, 1983.

6) Kodama, H., Amagai, Y., Sudo, H., Ohno, T. and lizima, K. : Culture conditions affecting differentiation and calcification in the MC 3T3E 1 osteogenic cell line. Excerpta Medica, Amsterdam I.C.S., 1986. 297-302,

7）小川浩美 : コッサ反応. 染色法のすべて, 三浦裕 士, 医歯薬出版, 東京, 1988, 94-96.

8）培養細胞の組織化学. 組織培養のてびき, 三光純 薬, 東京, 1982, 55-59.

9) Shima, M., Seino, Y., Tanaka, H., Kurose, H., Ishida, M., Yabuuchi, H. and Kodama, H. : Microcarriers facilitate mineralization in $\mathrm{MC}$ 3T3-E 1 cells. Calcif. Tissue Int., $43: 19-25$, 1988.

10）瀬口晴道 : alkaline phosphatase そ acid phosphatase. 水谷 昭, 組織細胞化学 1985, 学際企画, 東京, 1985, 7-21.

11）青木秀希, 丹羽滋郎, 立石哲也, バイオセラミッ クスの評価法. 青木秀希, 丹羽滋郎, バイオセラ ミックスの開発と臨床, クインテッセンス出版, 東京, 1987, 31-35.

12) Sudo, H., Kodama, H., Amagai, Y., Yamamoto, S. and Kasai, S. : In vitro differentiation and calcification in a new osteogenic cell line derived from new born mouse calvaria. J. Cell
Biol., 96 : 191-198, 1983.

13）佐々木哲 : カルシウムと骨形成. 蛋白質核酸酵素, 33 : 2324-2331, 1988.

14）辰巳順一，栗原徳善，高橋常男，下山雅道，唐見 和男, 池田克己 : 焼成骨の歯周治療への応用 (1) 一in vitro での検討一. 日歯周誌, $30: 164-171$, 1988.

15) Wlodarski, K.H. and Reddi A.H. : Alkaline phosphatase as a marker of osteoinductive cells. Calcif. Tissue Int., $39:$ 382-385, 1986.

16）小澤英浩，骨芽細胞. 須藤立雄，小澤英浩，高橋 栄明, 骨の科学, 医歯薬出版, 東京, 1985，4147.

17）安井良一, 藤本明秀, 下里常弘 : 組織培養法によ る人工根用結晶化ガラスの生体適合性について. ザ・サインテッセンス, $8: 137-144,1989$.

18) Levenson, G.E. : Behavior in culture of three types of chondrocytes, and their response to ascorbic acid. Exptl. Cell Res., 62 : 271-285, 1970.

19) Daniel, J.C., Pauli, B.U. and Kuttner K.E. : Synthesis of cartilage matrix mammalian chondrocytes in vitro. III. Effects of ascorbate J. Cell Biol., 99 : 1960-1969, 1984.

20) Sugimoto, T., Nakada, M., Fukase, M., Imai, Y., Kinoshita, Y. and Fujita, T. : Effects of ascorbic acid on alkaline phosphatase activity and hormone responsiveness in the osteoblastic osteosarcoma cell line UMR-106. Calcif. Tissue Int., 39 : 171-174, 1986.

21）飯島啓一郎，須藤博子，天貝裕地，新飯田俊平， 板倉良暢，大野 敬，山本茂久：アスコルビン酸 欠乏下における骨原性細胞株 MC 3T3-E 1 の分 化. 東北歯大誌, $14: 52-56,1987$.

22）三木克明，山室隆夫 : 細胞の反応からみた各種骨 移植材料の比較検討. 真角昭吾, 別冊整形外科 8 骨・軟骨移植の基礎 と臨床，南江堂，東京， 1985, 48-51.

連絡先 :

九州大学歯学部歯科保存学第一教室

₹ 812 福岡市東区馬出 $3-1-1$ 